\title{
Denitrification in a Soil under Wheat Crop in the Humid Pampas of Argentina
}

\author{
Liliana Inés Picone ${ }^{1 *}$, Cecilia Videla ${ }^{1}$, Calypso Lisa Picaud ${ }^{2}$, Fernando Oscar García ${ }^{3}$, \\ Roberto Héctor Rizzalli ${ }^{1}$ \\ ${ }^{1}$ Facultad Ciencias Agrarias, Unidad Integrada Balcarce Instituto Nacional Tecnología Agropecuaria (INTA) \\ UNMdP, Balcarce, Argentina \\ ${ }^{2}$ AgroParisTech, Institut des sciences et industries du vivant et de l'environnement, 16 rue Claude Bernard, \\ Paris, France \\ ${ }^{3}$ International Plant Nutrition Institute (IPNI), Programa Cono Sur de Latinoamérica, Buenos Aires, Argentina \\ Email: " picone.liliana@inta.gob.ar
}

Received 15 July 2014; revised 10 August 2014; accepted 29 August 2014

Copyright (C) 2014 by authors and Scientific Research Publishing Inc.

This work is licensed under the Creative Commons Attribution International License (CC BY). http://creativecommons.org/licenses/by/4.0/

(c) (i) Open Access

\section{Abstract}

The need to accurately estimate gaseous nitrogen losses from soils is required to have a better understanding of the processes involved as well as soil and environmental conditions, and management practices contributing to these emissions. The objective was to quantify the denitrification rate using undisturbed cores with acetylene, as related to nitrogen $(\mathrm{N})$ fertilization rate in a spring wheat crop (Triticum aestivum $L$.) under conventional tillage. Soil denitrification losses remained low throughout most of the growing season, when water-filled pore space (WFPS) was below $60 \%$, ranging from 0.79 to $447.3 \mathrm{~g} \mathrm{~N}_{2} \mathrm{O}-\mathrm{N} \mathrm{ha}^{-1}$. day $^{-1}$ in the fertilized plot and was less than $47.3 \mathrm{~g} \mathrm{~N}_{2} \mathrm{O}-\mathrm{N} \mathrm{ha}^{-1}$. day ${ }^{-1}$ in the control. Denitrification rates were the highest when $\mathrm{N}$ fertilizer was applied after frequent and intensive rain. A good correlation was found between the logarithm of the daily denitrification rate and WFPS $(r=0.67, n=90)$; however the $\mathrm{NO}_{3}-\mathrm{N}$ concentration was not a good indicator $(r=0.21, n=90)$. Cumulative $\mathrm{N}_{2} \mathrm{O}-\mathrm{N}$ losses by denitrification averaged 3.5 and $0.9 \mathrm{~kg} \mathrm{~N}_{2} \mathrm{O}-\mathrm{N} \mathrm{ha}^{-1}$ in the fertilized and unfertilized treatment, respectively, during a period of 4 months this difference was not significant. Most $\mathrm{N}_{2} \mathrm{O}-\mathrm{N}$ losses occurred early in the spring; therefore sampling schedules need to focus on this period.

\section{Keywords}

Nitrogen, Urea-N, Losses, Water Content, Soluble Organic Carbon

\footnotetext{
${ }^{*}$ Corresponding author.
} 


\section{Introduction}

The intensive use of natural resources by man, especially non-renewable natural resources has led to a gradual degradation of environmental quality, compromising the sustainability of ecosystems. One consequence of this intensification is global warming, caused by increasing concentration of atmospheric greenhouse gases such as nitrous oxide $\left(\mathrm{N}_{2} \mathrm{O}\right)$. Comparatively, $\mathrm{N}_{2} \mathrm{O}$ has a global warming potential 298 times higher than $\mathrm{CO}_{2}$ over a 100year time horizon [1]. This gas accounts for about $8 \%$ of the global annual emissions of anthropogenic greenhouse gases, and its concentration has increased considerably over the past few decades and continues to increase at an annual rate of $0.25 \%$ [1].

Nitrous oxide is produced in soils by microbial transformations during nitrification and denitrification processes [2]. Nitrification is the dominant process contributing to $\mathrm{N}_{2} \mathrm{O}$ emissions at water-filled pore space (WFPS) between 35\% and 60\% [3] while denitrification increases with increasing WFPS above 60\% [4]. Therefore, denitrification is considered as the predominant pathway responsible for $\mathrm{N}_{2} \mathrm{O}$ production, particularly under humid climates, and in very wet and waterlogged soils [5] [6]. Soil water content is commonly identified as the most important regulator of soil denitrification [7], but this process is also controlled by nitrate $\left(\mathrm{NO}_{3}-\mathrm{N}\right)$ concentration, available carbon (C) and other soil properties such as temperature and $\mathrm{pH}$ [8]. Due to the complex interactions among these factors, large temporal and spatial variations of $\mathrm{N}_{2} \mathrm{O}$ emissions are usually observed in cropland soils.

The soil and crop management practices can also regulate the $\mathrm{N}_{2} \mathrm{O}$ emissions through its effect on the mentioned soil properties. One agricultural management practice is the application of nitrogen (N) fertilizers that provides substrate for denitrification. Several studies have shown that the $\mathrm{N}_{2} \mathrm{O}$ emissions from agricultural soils increase with $\mathrm{N}$ application [9]-[12]. Worldwide, IPCC [1] has estimated that the emission factor is $1 \%$ of applied N. Zhang et al. [13] reported $\mathrm{N}$ losses by denitrification that increase with the fertilization rate, ranging from $0.28 \%$ to $0.49 \%$ of the applied $\mathrm{N}$ fertilizer in a winter wheat crop. In contrast, a study that evaluated the effects of water table management on denitrification during the corn growing season, showed no consistent differences between 120 and $200 \mathrm{~kg} \mathrm{~N}^{-1}$ rates [14]. The synchrony between the supply and demand of $\mathrm{N}$ is an important factor in determining the availability of soil $\mathrm{N}$ and release of $\mathrm{N}_{2} \mathrm{O}$ from agricultural soils. Fertilizer $\mathrm{N}$ application prior to crop planting results in increased soil $\mathrm{N}$ with no $\mathrm{N}$ uptake by plant and greater potential of $\mathrm{N}_{2} \mathrm{O}$ emissions. However, if the $\mathrm{N}$ fertilizer is used efficiently by the crop, for example by adjusting $\mathrm{N}$ applications to crop needs, less $\mathrm{N}_{2} \mathrm{O}$ should be generated and released to the atmosphere. In fact, in study conducted on maize crop under no-tillage, denitrification losses were greater when urea was applied at planting than those when fertilizer was applied at six leaf stage (V6) [10].

The Pampas region is the main producer of maize, wheat, sunflower and soybeans in Argentina and is one of the most important agricultural areas in the world [15], with climatic and soil conditions suitable for grain crop production. This region includes several sub-regions, one of which is the southeastern area of Buenos Aires province, with a cropped area of 0.7 million ha and a wheat production of 2.5 million Mg [16]. Field experiments conducted in that area have shown that the wheat crop yield has increased an average rate of $38 \mathrm{~kg} \cdot \mathrm{ha}^{-1}$. $\mathrm{yr}^{-1}$, as a result of increments in applied $\mathrm{N}$; however the $\mathrm{N}$ recovery efficiency in grain plant was low, ranging on average from $32 \%$ to $41 \%$ [17], depending on the timing of $\mathrm{N}$ fertilizer application and weather conditions. Then, it is probably that some mechanism of $\mathrm{N}$ loss is occurring in the soil and may help to explain the low $\mathrm{N}$ use efficiency by plants. In fact, the southeast wheat belt is characterized by a high probability of rainfall during the fallow and the early stages of the wheat crop periods, along with low evaporative demand [18]. This situation combined with availability of $\mathrm{NO}_{3}-\mathrm{N}$ from mineralization of organic $\mathrm{N}$ during the fallow period or from applied $\mathrm{N}$ fertilizer at sowing, likely results in favorable conditions for denitrification and associated $\mathrm{N}_{2} \mathrm{O}$ emissions.

In Argentina, the total greenhouse gas emissions were estimated at $238702.9 \mathrm{Gg}$ of $\mathrm{CO}_{2}$ equivalents in 2000 . Of this amount, $\mathrm{N}_{2} \mathrm{O}$ emissions from agricultural activities accounted for approximately 43\% [19]. The estimation of Argentina's greenhouse gas emissions is based on the IPCC methodology, which includes gas emission factors based on international gas emission studies. Research on $\mathrm{N}_{2} \mathrm{O}$ emissions in Argentina is crucial in order to set up an appropriate national inventory of greenhouse gases and to calculate the emission factors based on specific experimental measurements that could then be included in the IPCC methodology [20]. Therefore, more field investigation on $\mathrm{N}_{2} \mathrm{O}$ fluxes, about regulating factors and processes that contribute to $\mathrm{N}$ emissions, is needed to assess their contribution to the $\mathrm{N}$ cycling in order to adopt management practices leading to reduced emissions from agricultural soils. 
Therefore, the aims of this study were: 1 ) to quantify the denitrification rate related to $\mathrm{N}$ fertilization rate and 2) to identify the soil factors, such as water content and $\mathrm{NO}_{3}-\mathrm{N}$ concentration that control this process, in a wheat crop under conventional tillage.

\section{Methods and Materials}

\subsection{Site Description}

The denitrification measurements and the field experiment were conducted at the Balcarce-Experimental Station of the National Institute of Agricultural Technology (INTA), located in the southeastern area of Buenos Aires province, Argentina ( $37^{\circ} 45^{\prime} \mathrm{S}$ lat. $58^{\circ} 18^{\prime} \mathrm{W}$ long.; $130 \mathrm{~m}$ above sea level). The soil is a complex of a fine, mixed, thermic Typic Argiudoll and a fine, illitic, thermic Petrocalcic Paleudoll (USDA Soil Clasification). It has a loam texture, with an organic matter content of $58.4 \mathrm{~g} \cdot \mathrm{kg}^{-1}, 23.7 \mathrm{cmolc} \cdot \mathrm{kg}^{-1}$ of cation-exchange capacity and a pH of 5.8 (ratio soil:water, 1:2.5) in the top soil (0 - $20 \mathrm{~cm}$ depth).

The region has a humid-subhumid mesothermal climate with maximum and minimum monthly mean temperatures of $27.4^{\circ} \mathrm{C}$ and $3.1^{\circ} \mathrm{C}$ in January and July, respectively. The 40-yr average annual precipitation is 922.4 $\mathrm{mm}, 45 \%$ of which occurs during the growing season of wheat. Air temperature as well as precipitation during the experiment is shown in Figure 1.

\subsection{Experimental Design}

The overall field experiment was designed to compare the effects of two tillage systems: no tillage (NT) and conventional tillage (CT), each with two rates of $\mathrm{N}$ fertilization: 0 and $120 \mathrm{~kg} \mathrm{~N} \mathrm{ha}^{-1}$. The experimental design was a split-plot arrangement set as a randomized complete block with three replications. Tillage systems were applied to the main plots while the two fertility treatments were applied to the subplots. However, measurements of denitrification fluxes were only made on the CT treatment. The CT consisted of disking to mix crop residues into the soil, one moldboard plowing to the depth of $20 \mathrm{~cm}$ followed by one to three disking to the depth of 8 to $10 \mathrm{~cm}$, before wheat planting date. Plots were seeded with wheat (Triticum aestivum L.) in the second week of July and it was harvested early in December.

Nitrogen fertilizer was applied as urea at a rate of $120 \mathrm{~kg} \mathrm{~N} \mathrm{ha}^{-1}$ and it was broadcasted on the soil surface, three days before wheat planting. At sowing, the experiments were fertilized with $\mathrm{P}$ as triple superphosphate at a rate of $31 \mathrm{~kg} \mathrm{Pha}^{-1}$.

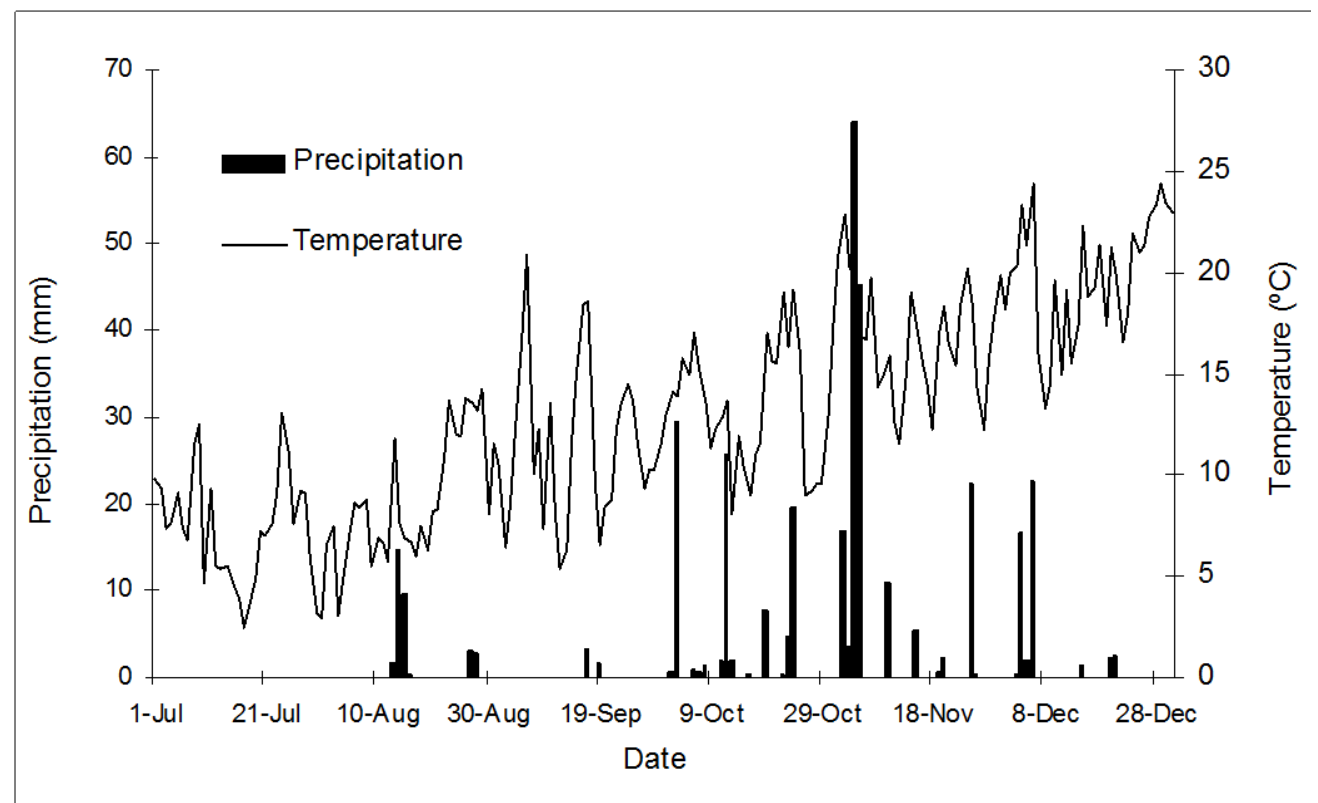

Figure 1. Rainfall and daily mean air temperatures during the growing season of spring wheat (JulyDecember). 


\subsection{Denitrification Measurements}

Denitrification rate measurements were made approximately weekly, during the wheat growing season, from early August (16 August) to mid-December (15 December) by the acetylene inhibition method [21]. Eight intact soil cores (4.2 cm in diameter by $15 \mathrm{~cm}$ long) were randomly taken from between rows in each plot using polyvinyl chloride cylinders (PVC) of 20-cm length. The cylinders were immediately brought to the lab, and both ends were capped with rubber stoppers, the upper stopper has a rubber septum for gas sampling. Approximately $10 \%$ of the headspace volume in the cylinder was removed using syringe and then an equivalent volume of acetylene (generated from calcium carbide and distilled water) was injected to the headspace. The cores were then incubated for 24 hours, outside in the shade. Gas samples were removed from each cylinder after 0 and 24 hours of incubation and subsequently stored in evacuated vials. The $\mathrm{N}_{2} \mathrm{O}$ concentration in a $1 \mathrm{~mL}$ gas sample was determined using a 5890 series-II Hewlett Packard (Palo Alto, CA) gas chromatograph equipped with a Porapak Q column at $35^{\circ} \mathrm{C}$ and a ${ }^{63} \mathrm{Ni}$-electron capture detector (ECD). The injector was set at $50^{\circ} \mathrm{C}$ and the $\mathrm{ECD}$ at $300^{\circ} \mathrm{C}$, and the carrier gas was $\mathrm{N}_{2}$ flowing at a rate of $15 \mathrm{~mL} \cdot \mathrm{min}^{-1}$.

Daily denitrification rates were calculated as the change in $\mathrm{N}_{2} \mathrm{O}$ concentration over the time using linear regression analysis. Denitrification rates were corrected for the $\mathrm{N}_{2} \mathrm{O}$ dissolved in the liquid phase using the Bunsen absorption coefficient [22]. Cumulative $\mathrm{N}_{2} \mathrm{O}$ losses over 4 months were calculated by interpolating linearly the daily denitrification rates between consecutives sampling dates and integrating the area.

\subsection{Soil Measurements}

At each date of denitrification rate measurement, the surface soil (0 - $15 \mathrm{~cm}$ depth) was sampled by collecting soil cores beside each cylinder for determination of $\mathrm{NO}_{3}-\mathrm{N}$ and gravimetric water content. Soil $\mathrm{NO}_{3}-\mathrm{N}_{\text {was }}$ extracted by shaking $20 \mathrm{~g}$ of field moist soil with $80 \mathrm{~mL}$ of $0.5 \mathrm{M} \mathrm{K}_{2} \mathrm{SO}_{4}$ solution (extractant:soil ratio of 4:1, w:w) for 1 hour at $200 \mathrm{rpm}$, and then filtering through filter paper (Whatman $\mathrm{N}^{\circ}$ 42). Filtrates were kept frozen until analyzed by steam distillation [23]. Gravimetric soil moisture was determined after oven drying of fresh subsamples at $105^{\circ} \mathrm{C}$ for 24 hours.

Soil samples (0 - $15 \mathrm{~cm}$ depth) for water-extractable organic C (WEOC) were taken monthly during the wheat growing season. The method of WEOC determination was adapted from Mebius [24]. Briefly, $10 \mathrm{~g}$ of fresh soil sample was shaken with $20 \mathrm{~mL}$ of distilled water for $30 \mathrm{~min}$ (140 rpm) and centrifuged at 19,500 g for 5 min. The supernatant was filtered through a 0.22 um membrane filter (Millipore Corp.) and analyzed for total organic $\mathrm{C}$ by dichromate oxidation in the presence of $\mathrm{H}_{2} \mathrm{SO}_{4}$, involving boiling and refluxing conditions during 30 min at $150^{\circ} \mathrm{C}$. The excess of dichromate was titrated with ferrous ammonium sulfate.

Soil bulk density was determined by the cylinder method [25]. Undisturbed soil cores (5 cm in diameter by 5 cm long) were taken from 0 to $15 \mathrm{~cm}$ depth. On average, bulk density was $1.20 \mathrm{Mg} \cdot \mathrm{m}^{-3}$ in the CT plots.

Gravimetric water content was converted to WFPS using the equation:

$$
\text { WFPS }=\left(\theta^{*} \delta\right) / f
$$

where: $\theta=$ gravimetric water content; $\delta=$ soil bulk density; $f=$ total soil porosity. Soil porosity was calculated from the average bulk density, assuming a particle density of $2.65 \mathrm{Mg} \cdot \mathrm{m}^{-3}$.

\subsection{Statistical Analysis}

The denitrification rate values were checked for normality using the Shapiro-Wilk test [26], and they were $\log _{10}$ transformed prior to statistical analysis due to the skewed distribution and unequal variance. The effect of fertilization rate on daily denitrification fluxes, WFPS, and $\mathrm{NO}_{3}-\mathrm{N}$ and WEOC contents was evaluated for each sampling date using the General Linear Model (GLM) procedure of SAS statistical program [27]. The PROC CORR function of SAS was used to determine the Pearson correlation coefficients between denitrification rates and $\mathrm{NO}_{3}-\mathrm{N}$ content using the individual data of each sampling date. A probability level of $\mathrm{p}=0.05$ was used to indicate significant differences.

\section{Results and Discussion}

\subsection{Air Temperature and Precipitation}

Over the 4-month evaluation period, the mean daily air temperature was $14.0^{\circ} \mathrm{C} \pm 5.0^{\circ} \mathrm{C}$, and ranged from $3^{\circ} \mathrm{C}(3$ 
August) to $24.4^{\circ} \mathrm{C}$ (6 and 29 December). The coldest month was August with air temperatures below $10^{\circ} \mathrm{C}$, and the warmest months were November and December with average temperatures equal or above $16.8^{\circ} \mathrm{C}$ (Figure 1). During the evaluation period, 38 days received precipitation, approximately $28 \%$ of the total period. Precipitations were more frequent and intensive in November and December, and less frequent in September. The lowest total precipitation occurred in September with only $4.9 \mathrm{~mm}$ of rainfall while the highest total precipitation was in October and November with 94.1 and $171.5 \mathrm{~mm}$, respectively (Figure 1).

\subsection{Soil Mineral Nitrogen, Water-Filled Pore Space and Water Extractable Organic Carbon}

There was a significant effect of the fertilized treatment on $\mathrm{NO}_{3}-\mathrm{N}$ concentration in the 0 to $15 \mathrm{~cm}$ depth. Application of $\mathrm{N}$ fertilizer resulted in higher $\mathrm{NO}_{3}-\mathrm{N}$ concentrations $(\mathrm{p}<0.05)$ in August, September, October and 17 November compared with the unfertilized treatment. Nitrate concentration was more than twice in the fertilized soil in comparison with the control soil. However, on 3, 8 and 22 November and during December, there were no differences ( $\mathrm{p}>0.05)$ in $\mathrm{NO}_{3}-\mathrm{N}$ level between both treatments (Figure 2).

The maximum value of soil $\mathrm{NO}_{3}-\mathrm{N}$ concentration of the control was $22.10 \mathrm{mg} \mathrm{N} \mathrm{kg}^{-1}$ at the beginning of the growing season, and gradually decreased to low values in December, below $5.88 \mathrm{mg} \mathrm{N} \mathrm{kg}^{-1}$ (Figure 2). Previous study conducted in these soils also showed relatively low inorganic $\mathrm{N}$ contents early in the growing season of wheat related to the fertilized treatment [28]. This initial concentration could be attributed to mineralization and subsequent nitrification of organic $\mathrm{N}$ from previous crop residues. For this site, the mineralized organic $\mathrm{N}$ estimated during a wheat season under CT was $65 \mathrm{~kg} \mathrm{~N} \mathrm{ha}^{-1}$ [29].

The highest content of $\mathrm{NO}_{3}-\mathrm{N}\left(82.22 \mathrm{mg} \mathrm{N} \mathrm{kg}{ }^{-1}\right)$ was found shortly after 1 month fertilizer application (Figure 2) and represents $108 \mathrm{~kg} \mathrm{~N} \mathrm{ha}^{-1}$ (subtracted the control), about $90 \%$ of the applied N. This result indicates that urea hydrolysis and $\mathrm{NH}_{4}$ oxidation was almost completed during this time. Ferrari [30] reported that soils from the study area exhibit high urease activity, $43.8 \mathrm{mg} \mathrm{N} \mathrm{kg}^{-1} \cdot \mathrm{h}^{-1}$, and thus high potential for urea hydrolysis. On the other hand, Navarro et al. [31] measuring nitrification rates under laboratory conditions, found that there was no delay in the nitrification process even with the highest concentration of ammonium, suggesting a high density of nitrifying microorganisms. This peak in $\mathrm{NO}_{3}-\mathrm{N}$ content was followed by a sharp decrease, probably caused by a combination of immobilization, plant uptake and gas emission by denitrification/ nitrification. A second fall in inorganic $\mathrm{N}$ in mid-October coincided with the early stem elongation to anthesis wheat stages, the period during which the crop can accumulate up to $75 \%$ of total $\mathrm{N}$ in above-ground biomass at maturity [32] [33]. At wheat physiological maturity, the soil $\mathrm{N}$ content reached values similar to those measured in the control.

The WFPS was not affected $(\mathrm{p}>0.05)$ by $\mathrm{N}$ application but fluctuated with time. It decreased from August to September, increased rapidly in response to rainfall events in October and November, and again decreased thereafter. The WFPS peaked on 16 August, 13 October and 8 November, reaching values higher than 50\% (Figure 3). These values of water content correspond to aeration conditions that encourage $\mathrm{N}_{2} \mathrm{O}$ production by both

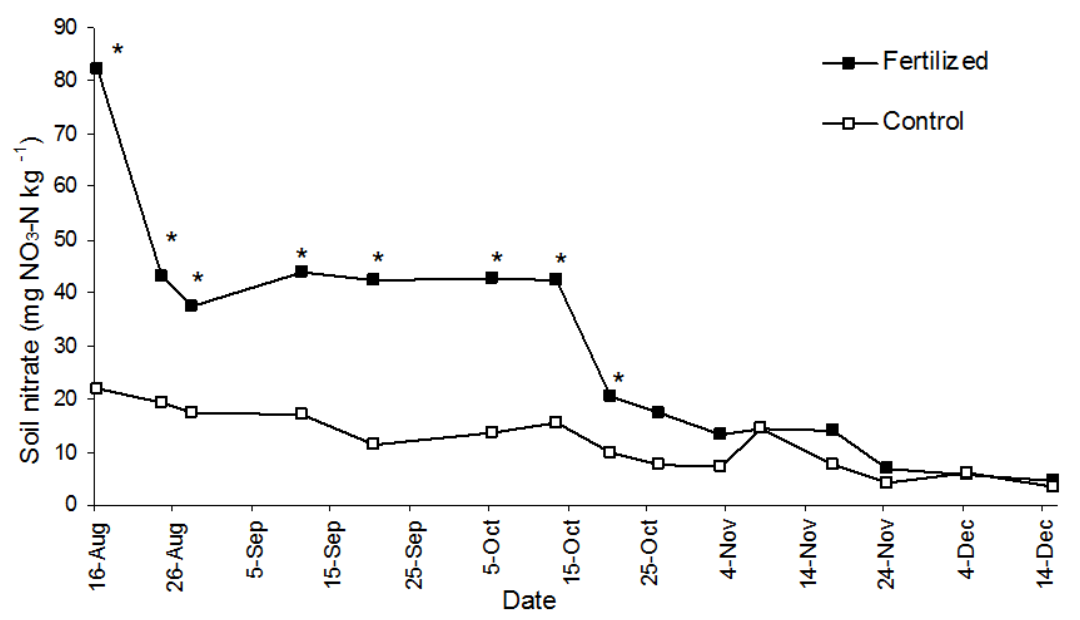

Figure 2. Soil nitrate $\left(\mathrm{NO}_{3}-\mathrm{N}\right)$ content in the 0 to $15 \mathrm{~cm}$ depth for the control (without $\mathrm{N}$ ) and fertilized treatments during the growing season of spring wheat. Asterisks indicate significant differences between both treatments $(p<0.05)$. 


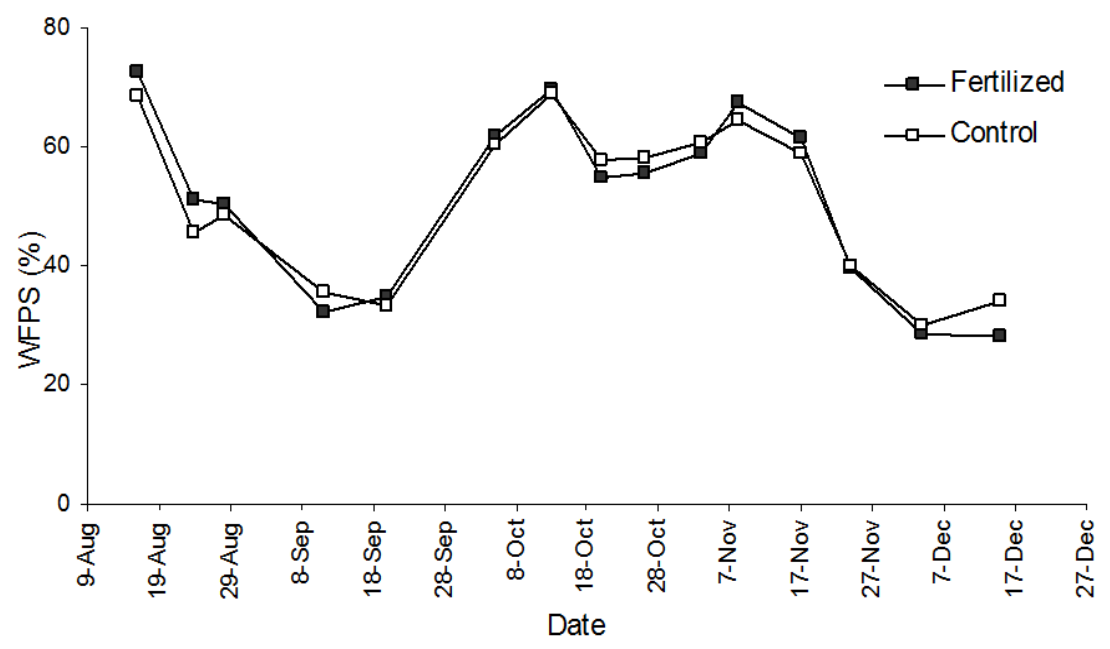

Figure 3. Distribution of soil water-filled pore space (WFPS) in the 0 to $15 \mathrm{~cm}$ depth for the control and fertilized treatments throughout the wheat growing season.

nitrification and denitrification [34]. The highest value of WFPS, 70\%, occurred immediately after several consecutive days of rain, corresponding to gravimetric water content of $0.36 \mathrm{~g} \cdot \mathrm{g}^{-1}$ which is higher than the water content at field capacity. Towards the end of the wheat growing season, the WFPS was about 28\%, close to the water content at permanent wilting point.

The mean concentration of soil WEOC was higher in the unfertilized treatment than in the fertilized treatment (Table 1), but the differences were only significant $(\mathrm{p}<0.05)$ in November. Trends toward lower WEOC in the fertilized treatment than in the unfertilized treatment suggest that WEOC in fertilized soils might have been metabolized at a greater rate. The WEOC concentrations remained relatively unchanged and low during the plant growth, ranging between 12.52 and $32.13 \mathrm{mg} \mathrm{C} \mathrm{kg}^{-1}$ (Table 1). Similar results were found by Elmi et al. [14] who reported that WEOC concentration was relatively uniform, ranging from 10 to $30 \mathrm{mg} \cdot \mathrm{kg}^{-1}$ (15 cm depth) in a corn field. The WEOC is a dynamic pool C, controlled by several physical and biological mechanisms. Sorption and desorption are two key processes for WEOC stabilization and production in soils, soluble root exudates and microbial processes can also contribute with dissolved $\mathrm{C}$, and plants and microorganisms can consume WEOC [35]. Then, the variety of factors determining the concentration of WEOC indicates that is difficult to explain its variation over the time in the soil.

\subsection{Daily Denitrification Rates}

Denitrification rates varied greatly throughout the wheat growing season, being more variable in the fertilized treatment (Figure 4). Daily rates of denitrification ranged from 0.776 to $472.83 \mathrm{ng} \mathrm{N}_{2} \mathrm{O}-\mathrm{N} \mathrm{cm}^{-2}$. day $^{-1}$ in the unfertilized treatment and from 0.789 to $4472.00 \mathrm{ng} \mathrm{N}_{2} \mathrm{O}-\mathrm{N} \mathrm{cm}^{-2}$. day $^{-1}$ in the fertilized treatment. Most of the time, denitrification rates were relatively low but on occasions increased to high values as $4472.00 \mathrm{ng} \mathrm{N} \mathrm{cm}^{-2}$. day $^{-1}$ on 13 October. This irregular pattern of denitrification rates has been shown by other experiments [36] [37] and was often the result of complex interactions among weather conditions, soil properties and management practices, each having specific effects on denitrification. In fact, the coefficients of variation (CV) of daily measurements ranged from 9 to $157 \%$ indicating a high spatial and temporal variability. Several studies showed a large variability of denitrification rates with coefficients of variation ranging from $70 \%$ to $379 \%$ when they were measured using intact cores and under field conditions [38]-[40].

Throughout August the fertilized treatment emitted more $\mathrm{N}_{2} \mathrm{O}-\mathrm{N}$ than the unfertilized treatment but the daily denitrification rate was only significantly different on 24 August $(\mathrm{p}<0.05)$. During this month, denitrification rate was relatively low $\left(<500 \mathrm{ng} \mathrm{N}_{2} \mathrm{O}-\mathrm{N} \mathrm{cm}^{-2}\right.$. day $^{-1}$ ) even though the $\mathrm{NO}_{3}-\mathrm{N}$ content was high, particularly in the fertilized treatment, and the WFPS ranged from $50 \%$ to $70 \%$. This means that other factors such as temperature and/or availability of $\mathrm{C}$, independent to inorganic $\mathrm{N}$ and water content, controlled $\mathrm{N}_{2} \mathrm{O}-\mathrm{N}$ losses by denitrification. Previous studies indicate that $\mathrm{C}$ availability is the most important limiting factor controlling denitrification, even in soils with low $\mathrm{NO}_{3}-\mathrm{N}$ contents [41] [42]. According to Burton and Beauchamp [43], soluble organic 
Table 1. Water-Extractable Organic Carbon (WEOC) concentration in soil from the control and fertilized treatments in the wheat growing season.

\begin{tabular}{ccc}
\hline Date & \multicolumn{2}{c}{ WEOC $\left(\mathrm{mg} \mathrm{C} \mathrm{kg}^{-1}\right)$} \\
\cline { 2 - 3 } & Control & Fertilized \\
\hline August & $23.80 \mathrm{a}$ & $22.45 \mathrm{a}$ \\
September & $32.13 \mathrm{a}$ & $21.73 \mathrm{a}$ \\
October & $13.20 \mathrm{a}$ & $12.52 \mathrm{a}$ \\
November & $17.89 \mathrm{a}$ & $14.13 \mathrm{~b}$ \\
December & $22.20 \mathrm{a}$ & $20.25 \mathrm{a}$ \\
\hline
\end{tabular}

Different letters within each row indicate significant differences $(\mathrm{p}<0.05)$ between treatments.

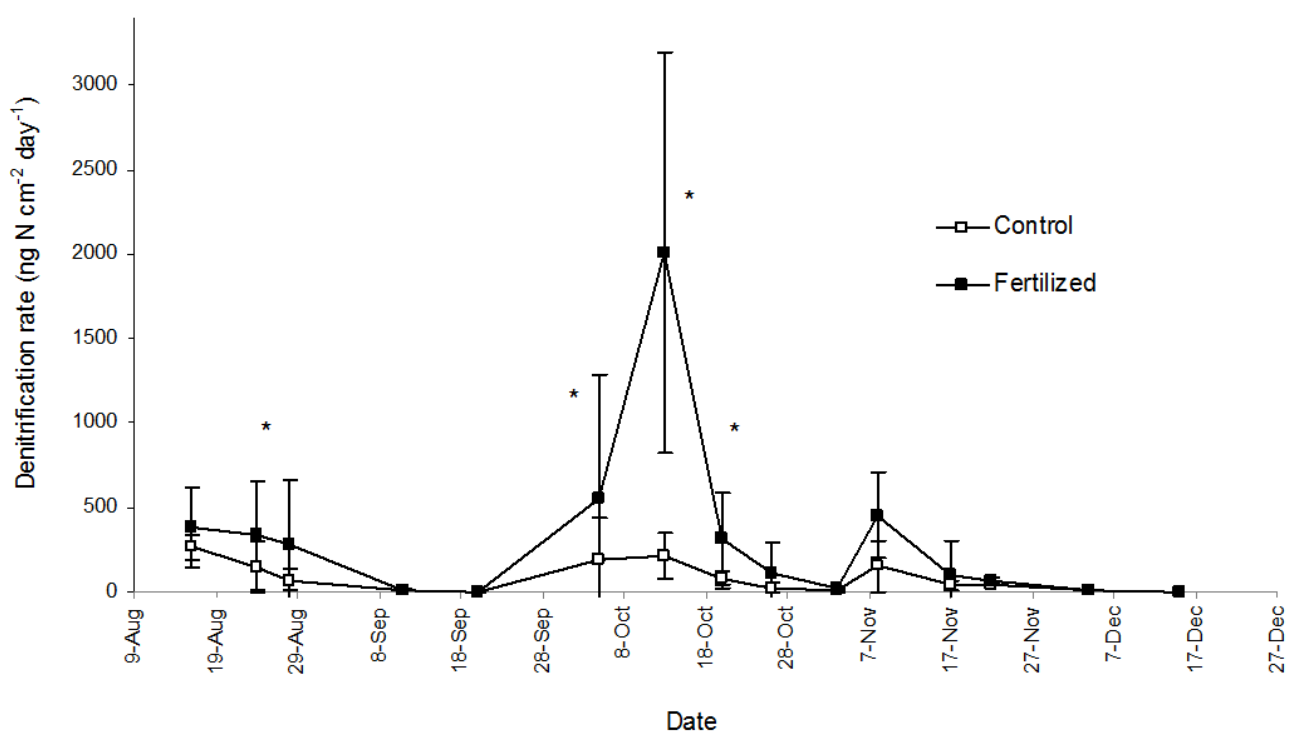

Figure 4. Daily denitrification rates ( $\mathrm{ng}_{2} \mathrm{O}-\mathrm{N} \mathrm{cm}^{-2}$.day ${ }^{-1}$ ) measured during the growth period of spring wheat. Vertical bars represent standard errors. Asterisks indicate significant differences between fertilized and nonfertilized treatments $(p<0.05)$.

C contents greater than 60 - $80 \mathrm{mg} \mathrm{C} \mathrm{kg}{ }^{-1}$ are required for denitrification. Since the WEOC levels measured during the growing season were less than $32.13 \mathrm{mg} \mathrm{C} \mathrm{kg}^{-1}$, it is possible that $\mathrm{C}$ was limiting this process during the crop growth. However, because the WEOC was measured each month and no more frequently, its concentration may not reflect accurately the effect on denitrification rate.

After this initial period, the daily denitrification rate decreased and was very low $\left(<20 \mathrm{ng} \mathrm{N} \mathrm{N}_{2} \mathrm{O}-\mathrm{N} \mathrm{cm}^{-2} \cdot \mathrm{day}^{-1}\right)$ during September. Soil water content was low, approaching 33\% WFPS during the dry phase from 28 August through 20 September, when the total rainfall was $9.6 \mathrm{~mm}$. However, a second peak of $\mathrm{N}_{2} \mathrm{O}$ occurred on 13 October following an increase in WFPS. The highest peak was recorded in the fertilized soil, after several rainfall events reflected in a WFPS of 70\%, and coinciding with an average $\mathrm{NO}_{3}-\mathrm{N}$ content of $25.35 \mathrm{mg} \mathrm{N} \mathrm{kg}^{-1}$. The denitrification rate of the fertilized soil was more than nine times the rate of the control soil, suggesting that $\mathrm{N}_{2} \mathrm{O}-\mathrm{N}$ production was driven mainly by $\mathrm{NO}_{3}-\mathrm{N}$ availability since all the other measured soil properties (available $\mathrm{C}$ and water content) were similar in both treatments. Previous studies have shown that $\mathrm{NO}_{3}-\mathrm{N}$ would not be the limiting factor unless all other parameters were optimized [44]. Then, $\mathrm{NO}_{3}-\mathrm{N}$ could be limiting when concentrations are lower than $5-10 \mathrm{mg} \mathrm{N} \mathrm{kg}^{-1}$ in a clay loam soil [45], $20 \mathrm{mg} \mathrm{N} \mathrm{kg}^{-1}$ under grassland soil [46] or $40 \mathrm{mg} \mathrm{N} \mathrm{kg}^{-1}$ in maize under no-tillage [10]. A small $\mathrm{N}_{2} \mathrm{O}-\mathrm{N}$ peak was observed on 8 November in the fertilized treatment, but the emissions were not statistically different $(p>0.05)$ between both treatments. Towards the end of the wheat growing season, WFPS and $\mathrm{NO}_{3}-\mathrm{N}$ concentration dropped to about $30 \%$ and $6 \mathrm{mg} \mathrm{N} \mathrm{kg}^{-1}$; respectively, while the corresponding denitrification rate decreased to less than $12.7 \mathrm{ng} \mathrm{N}_{2} \mathrm{O}-\mathrm{N} \mathrm{cm}^{-2}$. day ${ }^{-1}$. This result was probably consequence to depletion of soil $\mathrm{NO}_{3}-\mathrm{N}$ pool by plant uptake in combination with low water 
content leading to cessation of denitrification.

The active denitrification during spring appears to have been associated mainly with high soil moisture contents. It has been recognized that $\mathrm{O}_{2}$ concentrations can affect both synthesis and activity of denitrifying enzymes [47]. Denitrification increases with increases in WFPS and the maximum emission of $\mathrm{N}_{2} \mathrm{O}-\mathrm{N}$ by denitrification occurs at WFPS values $>60 \%$ [34] [48]. A high correlation between the logarithm of daily denitrification rate and WFPS $(r=0.67, \mathrm{n}=90)$ was found, although nearly all WFPS values are below $60 \%$ during the measurement period. On the other hand, although $\mathrm{NO}_{3}-\mathrm{N}$ concentration has been recognized to play a significant role in the regulation of denitrification process [49], it was not a good indicator of the logarithm of the denitrification rate because the relationship between both variables was weak $(r=0.21, n=90)$. Denitrification is maybe more influenced by the diffusion of the $\mathrm{NO}_{3}-\mathrm{N}$ to the active denitrification sites even at a high $\mathrm{NO}_{3}-\mathrm{N}$ concentration [45] than by the concentration of available $\mathrm{NO}_{3}-\mathrm{N}$.

\subsection{Cumulative $\mathrm{N}_{2} \mathrm{O}$ Losses}

Cumulative losses of $\mathrm{N}_{2} \mathrm{O}-\mathrm{N}$ for the 4-month period were lower for the unfertilized treatment compared with the fertilized treatment, but this difference was not statistically significant ( $p>0.05$ ). The high variability in $\mathrm{N}_{2} \mathrm{O}-\mathrm{N}$ rates probably overrides the statistical significances of the means. During the wheat season, the fertilized soil had a cumulative $\mathrm{N}_{2} \mathrm{O}-\mathrm{N}$ loss of $3.5 \mathrm{~kg} \mathrm{~N}_{2} \mathrm{O}-\mathrm{N} \mathrm{ha}^{-1}$ whereas it was $0.9 \mathrm{~kg} \mathrm{~N}_{2} \mathrm{O}-\mathrm{N} \mathrm{ha}^{-1}$ in the unfertlized soil (Figure 5). The results agree with those of Skiba et al. [11], and Granli and Bockman [50] who found higher total $\mathrm{N}_{2} \mathrm{O}$ losses from the fertilized treatment compared with the control. The emissions of $\mathrm{N}_{2} \mathrm{O}-\mathrm{N}$ by denitrification expressed as a percentage of applied $\mathrm{N}$ fertilizer were low, 2\%, after subtraction of $\mathrm{N}_{2} \mathrm{O}-\mathrm{N}$ emissions attributable to the control. For the non-fertilized plots, total $\mathrm{N}_{2} \mathrm{O}-\mathrm{N}$ losses were also low but this confirms that there are emissions even without $\mathrm{N}$ fertilization due to the potential for $\mathrm{N}$ mineralization of this soil.

Most cumulative $\mathrm{N}_{2} \mathrm{O}$ losses in the wheat crop, about $82 \%$, occurred early in the spring probably because of high precipitation, $\mathrm{NO}_{3}-\mathrm{N}$ availability and higher air temperature. This indicates the importance of this period for the evaluation of total $\mathrm{N}_{2} \mathrm{O}-\mathrm{N}$ losses from wheat crop, in temperate climate zones.

\subsection{Denitrification and Its Relationship to Other Loss Processes}

In this study, denitrification measurements were performed on a site where other aspects of the $\mathrm{N}$ cycle were measured. A previous study reported that ammonia volatilization losses from this soil were low, on average 1.69 $\mathrm{kg} \mathrm{N} \mathrm{ha}{ }^{-1}$, which represented $1.5 \%$ of the $\mathrm{N}$ fertilizer when $120 \mathrm{~kg} \mathrm{~N} \mathrm{ha}^{-1}$ of urea was applied at sowing of wheat

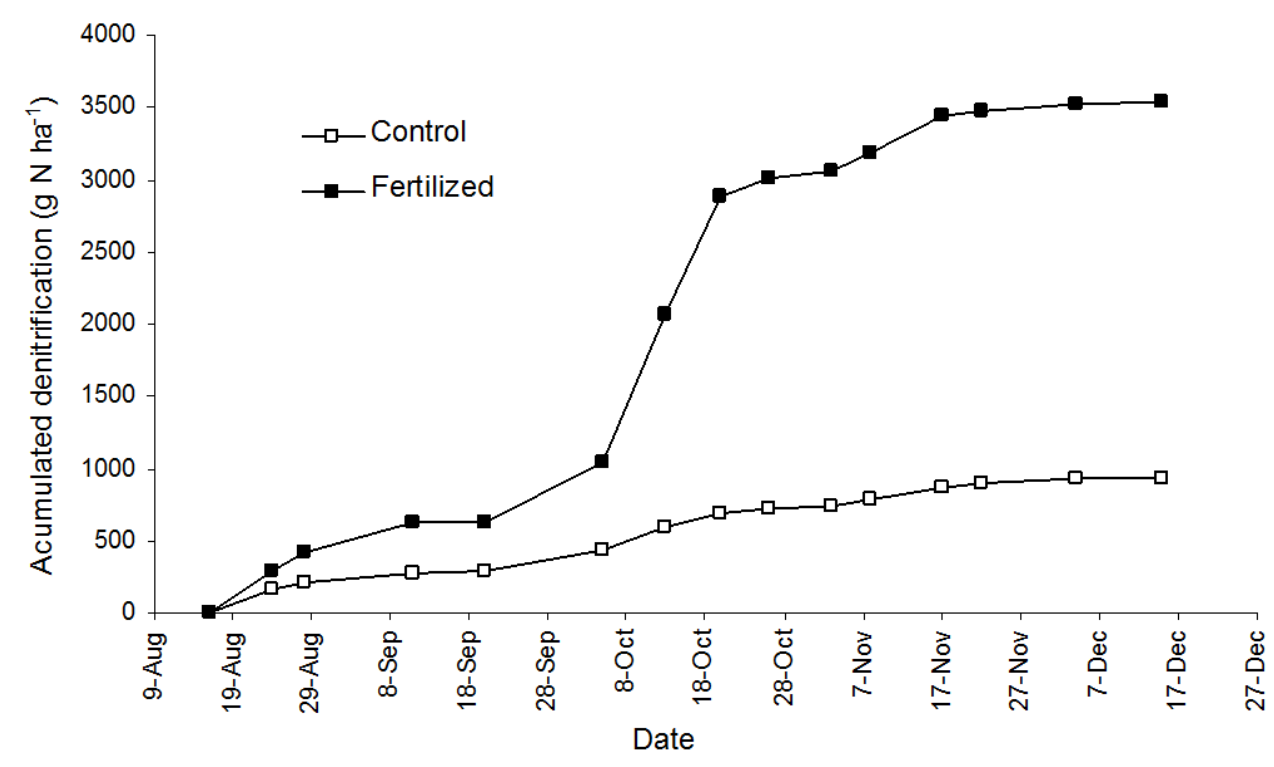

Figure 5. Cumulative $\mathrm{N}_{2} \mathrm{O}$ emissions $\left(\mathrm{g} \mathrm{N}_{2} \mathrm{O}-\mathrm{N} \mathrm{ha}^{-1}\right.$ ) by denitrification throughout the growing season of wheat (August-mid December) from the control and fertilized treatments. 
crop [28]. Using Ceres-Wheat model, it was predicted that $\mathrm{NO}_{3}-\mathrm{N}$ losses by leaching ranged from 12 to $62 \mathrm{~kg} \mathrm{~N}$ $\mathrm{ha}^{-1}$ for rates of 0 to $175 \mathrm{~kg} \mathrm{~N} \mathrm{ha}^{-1}$; respectively, while denitrification losses fluctuated between 1.2 and 3.9 $\mathrm{kg} \cdot \mathrm{N} \cdot \mathrm{ha}^{-1}$ depending on the $\mathrm{N}$ rate at sowing of wheat [17]. According to this information, the denitrification process was expected to be a minor pathway of $\mathrm{N}$ loss. In fact, the results of this research support this conclusion since $\mathrm{N}_{2} \mathrm{O}-\mathrm{N}$ rates measured by acetylene were comparable to those predicted by the model, $0.9 \mathrm{~kg} \mathrm{~N} \mathrm{ha}{ }^{-1}$ and $3.5 \mathrm{~kg} \mathrm{~N} \mathrm{ha}^{-1}$ in the control and fertilized plot; respectively. However, the lack of measurements during the first days immediately after $\mathrm{N}$ fertilizer application may have resulted in an underestimation of the cumulative $\mathrm{N}_{2} \mathrm{O}-\mathrm{N}$ loss as emissions could have occurred during that period. In addition, weather conditions during the study were drier $(350 \mathrm{~mm})$ than the median over the $1971-2003$ period $(489 \mathrm{~mm})$. This means that a median year could lead to higher $\mathrm{N}_{2} \mathrm{O}$ emissions than those measured in this study due to a higher rainfall.

\section{Conclusions}

The peaks of denitrification rate in the wheat crop were observed when $\mathrm{N}$ fertilizer was applied and rain was more frequent and intensive. A high correlation was found between daily denitrification rate and WFPS $(r=0.67$, $\mathrm{n}=90)$, however, the $\mathrm{NO}_{3}-\mathrm{N}$ soil concentration was not a good indicator of denitrification rate $(\mathrm{r}=0.21, \mathrm{n}=90)$. The accumulative $\mathrm{N}_{2} \mathrm{O}$ loss under spring wheat was not significantly different between the fertilized and control treatments. This is due to the high measured variability of denitrification rates. Denitrification process does not appear to be a major pathway for loss of $\mathrm{N}$ from this crop.

Denitrification rates were small considering that they represent $2 \%$ of the $\mathrm{N}$ added to the soil. Most cumulative $\mathrm{N}_{2} \mathrm{O}-\mathrm{N}$ losses occurred early in the spring (82\%). Therefore sampling schedules need to focus during this period for wheat crop, in temperate climate regions.

\section{References}

[1] IPCC (2006) Guidelines for National Greenhouse Gas Inventories Third Authors/Experts Meeting: Industrial Processes and Product Use, Washington D.C., 27-29 July 2004.

[2] Firestone, M.K. and Davidson, E.A. (1989) Microbiological Basis of NO and $\mathrm{N}_{2} \mathrm{O}$ Production and Consumption in Soils. In: Andreae, M.O. and Schimel, D.S., Eds., Exchange of Trace Gases between Terrestrial Ecosystems and the Atmosphere, John Willey and Sons, New York, 7-21.

[3] Bateman, E.J. and Baggs, E.M. (2005) Contributions of Nitrification and Denitrification to $\mathrm{N}_{2} \mathrm{O}$ Emissions from Soils at Different Water-Filled Pore Space. Biology and Fertility of Soils, 41, 379-388. http://dx.doi.org/10.1007/s00374-005-0858-3

[4] Drury, C.F., Zhang, T.Q. and Kay, B.D. (2003) The Non-Limiting and Least Limiting Water Ranges for Soil Nitrogen Mineralization. Soil Science Society of American Journal, 67, 1388-1404. http://dx.doi.org/10.2136/sssaj2003.1388

[5] Parton, W.J., Mosier, A.R. and Schimel, D.S. (1988) Rates and Pathways of Nitrous Oxide Production in a Shortgrass Steppe. Biogeochemistry, 6, 45-48. http://dx.doi.org/10.1007/BF00002932

[6] Skiba, U., Smith, K.A. and Fowler, D. (1993) Nitrification and Denitrification as Sources of Nitric Oxide and Nitrous Oxide in a Sandy Loam Soil. Soil Biology and Biochemistry, 25, 1527-1536. http://dx.doi.org/10.1016/0038-0717(93)90007-X

[7] Coyne, M.S. (2008) Biological Denitrification. In: Schepers, J.S. and Raun, W.R., Eds., Nitrogen in Agricultural Systems, American Society of Agronomy, Crop Science Society of America. Soil Science Society of America, Madison, 202-254. http://dx.doi.org/10.2134/agronmonogr49.c7

[8] Firestone, M.K. (1982) Biological Denitrification. In: Stevenson, F.J., Ed., Nitrogen Agricultural Soils. Agron. Monogr. 22. American Society Agronomy, Crop Science Society of America and Soil Science Society of American, Madison, 289-326.

[9] Grant, R.F., Pattey, E., Goddard, T.W., Kryzanowski, L.M. and Puurveen, H. (2006) Modeling the Effects of Fertilizer Application Rate on Nitrous Oxide Emissions. Soil Science Society of American Journal, 70, 235-248. http://dx.doi.org/10.2136/sssaj2005.0104

[10] Sainz Rozas, H., Echeverría, H.E. and Picone, L.I. (2001) Denitrification in Maize No-Tillage: Effect of Nitrogen Rate and Application Time. Soil Science Society of American Journal, 65, 1314-1323. http://dx.doi.org/10.2136/sssaj2001.6541314x

[11] Skiba, U., Fowler, D. and Smith, K. (1994) Emissions of NO and $\mathrm{N}_{2} \mathrm{O}$ from Soils. Environmental Monitoring and Assessment, 31, 153-158. http://dx.doi.org/10.1007/BF00547191

[12] Stehfest, E. and Bouwman, L. (2006) $\mathrm{N}_{2} \mathrm{O}$ and NO Emission from Agricultural Fields and Soils under Natural Vegeta- 
tion: Summarizing Available Measurement Data and Modeling of Global Annual Emissions. Nutrient Cycling in Agroecosystems, 74, 207-228. http://dx.doi.org/10.1007/s10705-006-9000-7

[13] Zhang, Y.M., Chen, D.L., Zhang, J.B., Edis, R., Hu, C.S. and Zhu, A.N. (2004) Ammonia Volatilization and Denitrification Losses from an Irrigated Maize-Wheat Rotation Field in the North China Plain. Pedosphere, 14, 533-540.

[14] Elmi, A.A., Astatkie, T., Madramootoo, C., Gordon, R. and Burton, D. (2005) Assessment of Denitrification Gaseous End Products in the Soil Profile under Two Water Table Management Practices Using Repeated Measures Analysis. Journal of Environmental Quality, 34, 446-454. http://dx.doi.org/10.2134/jeq2005.0446

[15] Satorre, E.H. and Slafer, G.A. (1999) Wheat Production Systems of the Pampas. In: Wheat: Ecology and Physiology of Yield Determination, Food Products Press, New York, 333-348.

[16] Reussi Calvo, N., Sainz Rozas, H., Echeverría, H. and Berardo, A. (2013) Contribution of Anaerobically Incubated Nitrogen to the Diagnosis of Nitrogen Status in Spring Wheat. Agronomy Journal, 105, 321-328. http://dx.doi.org/10.2134/agronj2012.0287

[17] Barbieri, P.A., Rozas, H.S. and Echeverría, H.E. (2008) Time of Nitrogen Application Affects Nitrogen Use Efficiency of Wheat in the Humid Pampas of Argentina. Canadian Journal of Plant Science, 88, 849-857. http://dx.doi.org/10.4141/CJPS07026

[18] Calviño, P.A. and Sadras, V.O. (2002) On-Farm Assessment of Constraints to Wheat Yield in the South-Eastern Pampas. Field Crops Research, 74, 1-11. http://dx.doi.org/10.1016/S0378-4290(01)00193-9

[19] Gobierno Argentino (2007) Segunda Comunicación Nacional del Gobierno Argentino a la Convención Marco de las Naciones Unidas sobre Cambio Climático. Proyecto BIRF No. TFO51287. http://www.fundacionbariloche.org.ar

[20] Taboada, M.A. and Cosentino, V.R.N. (2012) Emisión de óxido nitroso $\left(\mathrm{N}_{2} 0\right)$ desde suelos agrícolas. XIX Congreso Latino Americano de la ciencia del suelo, XXIII Congreso argentino de la Ciencia del suelo, 16-20 abril 2012, Resumen en actas.

[21] Yoshinari, T., Hynes, R. and Knowles, R. (1977) Acetylene Inhibition of Nitrous Oxide Reduction and Measurement of Denitrification and Nitrogen Fixation in Soil. Soil Biology and Biochemistry, 9, 177-183. http://dx.doi.org/10.1016/0038-0717(77)90072-4

[22] Tiedje, J.M. (1982) Denitrification. In: Page, A.L., Ed., Methods of Soil Analysis: Part 2. Microbiological and Biochemical Properties, Agron. Monogr. 9, American Society of Agronomy and Soil Science Society American, Madison, 1011-1026.

[23] Keeney, D.R. and Nelson, D.W. (1982) Nitrogen Inorganic Forms. In: Page, A.L., Ed., Methods of Soil Analysis Part 2 Chemical and Microbiological Properties, American Science of Agronomy and Soil Science Society of America, Madison, 643-693.

[24] Mebius, L.J. (1960) A Rapid Method for the Determination of Organic Carbon in Soil. Analytica Chimica Acta, 22, 120-124. http://dx.doi.org/10.1016/S0003-2670(00)88254-9

[25] Blake, G.R. and Hartge, K.H. (1986) Bulk Density. In: Klute, A., Ed., Methods of Soil Analysis, Part 1, 2nd Edition, Agron. Monogr. 9, American Society of Agronomy and Soil Science Society of America, Madison, 363-375.

[26] Shapiro, S.S. and Wilk, M.B. (1965) An Analysis of Variance Test for Normality (Complete Samples). Biometrika, 52, 591-611. http://dx.doi.org/10.1093/biomet/52.3-4.591

[27] SAS Institute Inc. (1988) User’s Guide: Statistics. Version 6.03 ed. SAS/STAT. SAS Inst., Cary.

[28] Videla, C.C., Ferrari, J.L., Echeverria, H.E. and Travasso, M.I. (1996) Transformaciones del nitrógeno en el cultivo de trigo. Ciencia del suelo, 14, 1-6.

[29] García, F. and Fabrizzi, K. (2001) Dinámica del nitrógeno en ecosistemas agrícolas: Efecto de la siembra directa. Siembra directa en el Cono Sur. Programa cooperativo para el desarrollo tecnológico agroalimentario y agroindustrial del Cono Sur. Instituto Interamericano de Cooperación para la Agricultura, Procisur, Montevideo, 299-323.

[30] Ferrari, M.H. (1995) Hidrólisis de la urea en suelos de la region pampeana. Tesis Ing. Agr. Facultad de Ciencias Agrarias, UNMdP, Balcarce.

[31] Navarro, C.A., Echeverría, H.E., Gonzalez, N.S. and Iglesias, M.A. (1980) Cinética de las reacciones de amonificación y nitrificación en algunos suelos de Argentina. IX Reunión Argentina de la Ciencia del Suelo, 15 al 20 septiembre 1980, 431-437.

[32] Abbate, P.E. and Andrade, F.H. (2006) Los nutrientes del suelo y la determinación del rendimiento de los cultivos de grano. In: Echeverría, H.E. and García, F.O., Eds., Fertilidad de suelos y fertilización de cultivos, Editorial INTA, 43-65.

[33] Baethgen, W.E. and Alley, M.M. (1989) Optimizing Soil and Fertilizer Nitrogen Use for Intensively Managed Winter Wheat. I. Crop Nitrogen Uptake. Agronomy Journal, 81, 116-120.

[34] Linn, D.M. and Doran, J.W. (1984) Effect of Water Filled Pore Space on Carbon Dioxide and Nitrous Oxide Produc- 
tion in Tilled and Non-Tilled Soils. Soil Science Society of America Journal, 48, 1267-1272. http://dx.doi.org/10.2136/sssaj1984.03615995004800060013x

[35] Neff, J.C. and Asner, G.P. (2001) Dissolved Organic Carbon in Terrestrial Ecosystems: Synthesis and a Model. Ecosystems, 4, 29-48. http://dx.doi.org/10.1007/s100210000058

[36] Hénault, C., Grossel, A., Mary, B., Roussel, M. and Léonard, J. (2012) Nitrous Oxide Emission by Agricultural Soils: A Review of Spatial and Temporal Variability for Mitigation. Pedosphere, 22, 426-433. http://dx.doi.org/10.1016/S1002-0160(12)60029-0

[37] Mathieu, O., Lévêque, J., Hénault, C., Milloux, M.J., Bizouard, F. and Andreux, F. (2006) Emissions and Spatial Variability of $\mathrm{N}_{2} \mathrm{O}, \mathrm{N}_{2}$ and Nitrous Oxide Mole Fraction at the Field Scale, Revealed with ${ }^{15} \mathrm{~N}$ Isotopic Techniques. Soil Biology and Biochemistry, 38, 941-951. http://dx.doi.org/10.1016/j.soilbio.2005.08.010

[38] Folorunso, O.A. and Rolston, D.E. (1984) Spatial Variability of Field Measured Denitrification Gas Fluxes. Soil Science Society of America Journal, 48, 1214-1219. http://dx.doi.org/10.2136/sssaj1984.03615995004800060002x

[39] Parkin, T.B., Kaspar, H.F., Sextone, A.J. and Tiedje, J.M. (1984) A Gas-Flow Soil Method to Measure Field Denitrification Rates. Soil Biology and Biochemistry, 16, 323-330. http://dx.doi.org/10.1016/0038-0717(84)90026-9

[40] Parsons, L., Scott Smith, M. and Murray, R.E. (1991) Soil Denitrification Dynamics: Spatial and Temporal Variations of Enzyme Activity, Populations and Nitrogen Gas Loss. Soil Science Society of America Journal, 55, 90-95. http://dx.doi.org/10.2136/sssaj1991.03615995005500010016x

[41] Drury, C.F., McKenney, D.J. and Findlay, W.I. (1991) Relationships between Denitrification, Microbial Biomass and Indigenous Soil Properties. Soil Biology and Biochemistry, 23, 751-755. http://dx.doi.org/10.1016/0038-0717(91)90145-A

[42] Weier, K.L., Doran, J.W., Power, J.F. and Walters, D.T. (1993) Denitrification and the Dinitrogen/Nitrous Oxide Ratio as Affected by Soil Water, Available Carbon and Nitrate. Soil Science Society of America Journal, 57, 66-72. http://dx.doi.org/10.2136/sssaj1993.03615995005700010013x

[43] Burton, D.L. and Beauchamp, E.G. (1985) Denitrification Rate Relationship with Soil Parameters in the Field. Communications in Soil Science and Plant Analysis, 16, 539-549. http://dx.doi.org/10.1080/00103628509367626

[44] Vinther, F.P. (1984) Total Denitrification and the Ratio between $\mathrm{N}_{2} \mathrm{O}$ and $\mathrm{N}_{2}$ during the Growth of Spring Barley. Plant and Soil, 76, 227-232. http://dx.doi.org/10.1007/BF02205582

[45] Ryden, J.C. (1983) Denitrification Loss from a Grassland Soil in the Field Receiving Different Rates of Nitrogen as Ammonium Nitrate. Journal of Soil Science, 34, 355-365. http://dx.doi.org/10.1111/j.1365-2389.1983.tb01041.x

[46] Myrold, D.D. and Tiedje, J.M. (1985) Establishment of Denitrification Capacity in Soil: Effects of Carbon, Nitrate and Moisture. Soil Biology and Biochemistry, 17, 819-822. http://dx.doi.org/10.1016/0038-0717(85)90140-3

[47] Dendooven, L. and Anderson, J.M. (1994) Dynamics of Reduction Enzymes Involved in the Denitrification Process in Pasture Soil. Soil Biology and Biochemistry, 26, 1501-1506. http://dx.doi.org/10.1016/0038-0717(94)90091-4

[48] Davidson, E.A. (1991) Fluxes of Nitrous Oxide and Nitric Oxide from Terrestrial Ecosystems. In: Rogers, J.E. and Whitman, W.B., Eds., Microbial Production and Consumption of Greenhouse Gases: Methane, Nitrogen Oxide, and Halomethanes, ASM Press, Washington DC, 219-235.

[49] Tiedje, J.M. (1988) Ecology of Denitrification and Dissimilatory Nitrate Reduction to Ammonium. In: Zehnder, A.J.B., Ed., Biology of Anaerobic Microorganisms, John Wiley and Sons, New York, 179-244.

[50] Granli, T. and Bøckman, O.C. (1994) Nitrous Oxide from Agriculture. Norwegian Journal of Agricultural Sciences, 12, $1-128$. 
Scientific Research Publishing (SCIRP) is one of the largest Open Access journal publishers. It is currently publishing more than 200 open access, online, peer-reviewed journals covering a wide range of academic disciplines. SCIRP serves the worldwide academic communities and contributes to the progress and application of science with its publication.

Other selected journals from SCIRP are listed as below. Submit your manuscript to us via either submit@scirp.org or Online Submission Portal.
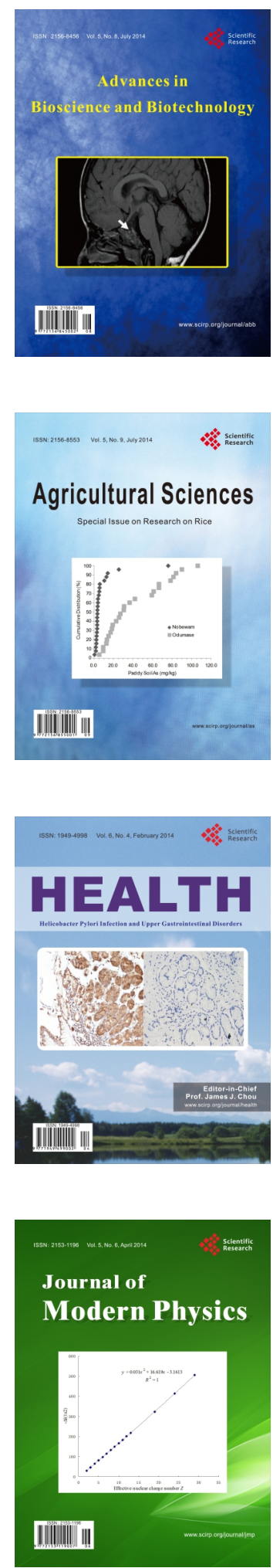
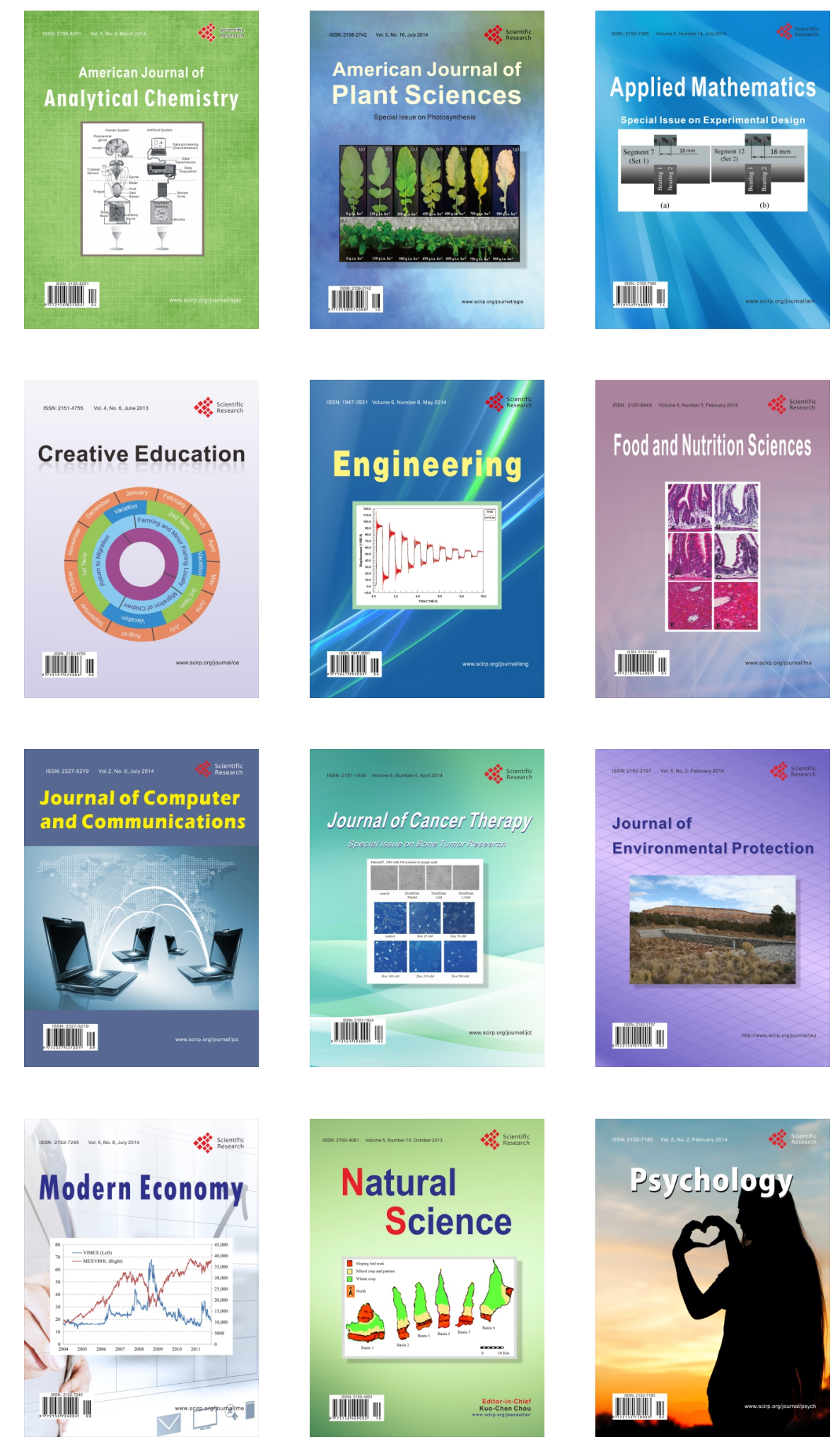